\title{
JOSÉ WAZEN DA ROCHA, 1932-2005
}

\section{TCBC Orlando Marques Vieira - Ex-Presidente do Colégio Brasileiro de Cirurgiões}

A notícia da morte de José Wazen da Rocha ocorrida no dia 17 de julho de 2005, deixou consternada a comunidade cirúrgica brasileira, em todos os seus segmentos. O Colégio Brasileiro de Cirurgiões, sem dúvida, por demais pesaroso.

Médico, cirurgião invulgar exerceu em plenitude a ação assistencial aliada ao exercício da vocação cirúrgica que continha em sua estrutura profissional. De caráter retilíneo, tinha por essência uma personalidade marcada pelo cumprimento do dever e lealdade às instituições que freqüentou e aos colegas.

Nasceu no Rio de Janeiro, cresceu no bairro da Tijuca, portanto carioca de nascimento e vocação. Fez seu curso secundário no Colégio Militar do Rio de Janeiro, onde com presença brilhante chegou a oficial aluno. Respeitado naquele educandário não se encantou pela carreira militar.

Resolveu, então ingressar na Faculdade de Medicina da hoje Universidade Federal do Rio de Janeiro (UFRJ), na ocasião na "Praia Vermelha". Desde os primeiros anos na faculdade se destacou como aluno e transmitia a alegria e a vontade de vencer a um grupo de colegas que sempre o estimou.

Ainda na faculdade inclinou-se pela cirurgia e desde os primeiros anos de acadêmico começou a freqüentar a $13^{\mathrm{a}}$ Enfermaria da Santa Casa de Misericórdia, então chefiada pelo Dr. Darcy Monteiro, que tinha como chefe de clínica o Dr. Alfredo Wazen, seu tio. Naquela Enfermaria permaneceu durante todo o curso médico.

Formou-se em dezembro de 1956 e o tive como colega de turma. Fomos paraninfados pelo Prof. Paulo Lacaz, Mestre que sempre nos acompanhou como diletos afilhados.

Como cirurgião, já habilitado, e já pertencendo aos quadros da Previdência Social incorporou-se ao Hospital do Andaraí, onde teve a consagração e reconhecimento profissional, como cirurgião, como chefe de Serviço e como Diretor.

O destino, no entanto, reserva surpresas e no correr de sua vida um rude golpe o surpreende, de modo dramático, e perde seu filho único, com doze anos de idade, vítima de um atropelamento. Abalado, mas firme na profissão, abraçou a cirurgia com amor e dedicação nos Serviços do Hospital do Andaraí. Lá se apegou com grande determinação ao atendimento dos pacientes e à expansão das atividades. Criou, jun- to com outros colegas, o "Centro de Hemorragia Digestiva", Serviço de atuação magistral e que atingiu reconhecimento internacional.Trabalho magnífico.

Mas os homens justos, abnegados, competentes e realizadores estão sujeitos aos duros reveses. Com dedicação integral ao Hospital do Andaraí foi aposentado compulsoriamente, como cirurgião do INSS, em 1992, juntamente com outros grandes nomes da medicina, pelo então Ministro da Saúde. Sofreu mais um duro golpe, desta vez na vida profissional.

Despojado de sua militância no hospital público integrou-se à medicina privada. Competente, como sempre, foi envolvido pelo palio dos colegas, principalmente, do grupo AMIL e seus hospitais, onde conseguiu desenvolver não só a cirurgia, como também, a sua capacidade científica e administrativa.

Distinguiu-se na carreira profissional e na vida associativa. Nesta última, principalmente no Colégio Brasileiro de Cirurgiões ocupou diversos cargos e chegou à Presidência Nacional no biênio 2002/2003. Representou, sem dúvida, na instituição o cirurgião dedicado ao "Hospital Público" e à medicina previdenciária. Sempre com atuações marcantes presidiu o Congresso Brasileiro de Cirurgia, realizado em Porto Alegre em julho de 2003.

Outro obstáculo o atormentou em sua vida. Coronariopata foi operado e desenvolveu a seguir uma hepatite com evolução grave que o acompanhou durante anos, e o levou a uma evolução desfavorável , mas sempre lutando contra este quadro adverso, até ser vencido.

Admirador de Fernando Pessoa, sempre o citava em seus pronunciamentos e discurso, e procurava com esta prática transmitir ensinamentos de vida.

Nada mais eloqüente ao terminarmos, agora, de lembrar o escritor a quem tanto respeitava, e para tal é importante citar um de seus trechos mais bonitos de sua prosa, e que espelha a grandeza de nosso querido José Wazen, e que seria um de seus escolhidos, naturalmente, por ele: "Tenho pensamentos que, se pudesse revelá-los e fazê-los viver, acrescentariam novas luminosidades às estrelas, nova beleza ao mundo e maior amor ao coração dos homens".

Ao José Wazen nossa eterna saudade. 